\title{
ANTROPOLOGIA DA MORTE
}

\author{
Anthropology of Death
}

Renato Alves de Oliveira *

RESUMO: Este artigo trata da antropologia da morte no horizonte teológico. Historicamente, ela foi definida como separação do corpo e da alma. Esta definição goza de uma insuficiência antropológica e existencial. A morte é um tema que pertence primeiramente à antropologia e posteriormente à escatologia. No campo antropológico, a morte é a possibilidade humana por excelência, goza de uma presença constante na vida e significa o fim do ser humano, na dimensão corpóreo-anímica, mundana e social. E a conclusão da condição peregrina, espaço-temporal e histórica do ser humano. Trata-se de um evento irrepetível que o ser humano simultaneamente padece e assume. É o último ato da história da liberdade humana e pode ser vista como um evento que consagra a existência. Com a morte, a existência alcança definitividade. Serão apresentadas as mudanças e deslocamentos antropológicos da morte no horizonte teológico a partir da segunda metade do século XX.

PALAVRAS-CHAVE: Vida. Ser humano. Morte. Consagração. Teologia.

\begin{abstract}
This paper discusses the anthropology of death from a theological viewpoint. Historically, death has been defined as the separation between body and soul. However, this definition is anthropologically and existentially insufficient. Death is a theme belonging primarily to anthropology and secondarily to eschatology. Anthropologically, death is the human possibility par excellence. It is constantly present and means the end of human beings in their bodily, worldly, and social dimensions. Death is the end of the human pilgrimage, in its spatial, temporal, and historical dimension, an unrepeatable event that we both suffer and accept. It is the last act of the history of human freedom and can be seen as an event that reaffirms our existence that, with death, achieves definiteness.
\end{abstract}

KEYWORDS: Life. Human Being. Death. Consecration. Theology.

* Pontifícia Universidade Católica de Minas Gerais, Belo Horizonte, Minas Gerais, Brasil. 


\section{Introdução}

morte é um tema, por excelência, antropológico. Trata-se do máximo
crita entre o numascimento e a morte. A vida humana, em sua fragilidade,
está constantemente ameaçada pela morte. Todo ser humano, um dia
se encontrará diante do último ato de sua existência. Ela é uma certeza
inegociável e irrefutável que palpita dentro da vida humana. A data de
validade da vida se conclui com a morte. Trata-se de uma experiência
exclusivamente reservada àquele que a prova e de uma experiência indi-
vidual, intransferível e certa. É um desígnio indeterminado: certo, mas a
hora é incerta.

A morte não possui somente uma dimensão antropológica, mas também teológica, ou seja, diz respeito à relação com Deus. A comunhão com Deus experimentada durante a vida é intensificada no momento da morte; ela é uma ocasião de encontro e de uma relação profunda com Deus. O ser humano, criado por Deus, por um ato de amor, não será abandonado por ele no momento final da morte; ela, na realidade, revela a identidade de Deus. O Deus no qual o ser humano crê, particularmente o cristão, não é um Deus dos mortos, que quer o fim trágico da sua criatura, mas é um Deus vivo que mostra sua força e sua potência transformadora e ressuscitadora diante do poder aniquilante da morte.

Primeiramente, será a abordada a definição clássica da morte (separação do corpo e da alma) e sua insuficiência humana, pessoal e existencial. Em seguida, será mostrado que, historicamente, o assunto foi tratado numa dimensão escatológica e ignorado no seu impacto antropológico. Ela foi vista como um evento propedêutico da vida pós-mortal. Negligenciava-a para refletir sobre os eventos da vida pós-mortal. Depois, mostrar-se-á que a morte é o fim do ser humano todo (na dimensão corpóreo-anímica, mundana e social), que ela consiste na possibilidade humana por excelência e goza de uma presença constante na vida. Seguindo em frente, se demonstrará que a morte é a conclusão da condição peregrina, espaço-temporal e histórica do ser humano. Com a sua realização, a vida conquista um rosto irrevogável e irreformável. Depois, se descreverá que ela é uma unidade dialética de paixão e de ação. É simultaneamente um evento que o ser humano padece e uma realidade que ele assume enquanto pessoal. Seguindo adiante, se abordará que o evento em questão é a consagração da história da liberdade e é a última possibilidade, o derradeiro ato da liberdade humana. Por último, será abordada a hipótese da decisão final e suas críticas sofridas.

O texto se pautará por uma impostação antropológica com um horizonte teológico. Serão apresentadas as mudanças e os descolamentos antropológicos ocorridos na abordagem do tema em questão. Depois de apresentar 
a limitação antropológica da visão clássica, o texto mostrará uma visão antropológico-existencial do tema em questão a partir da segunda metade do século XX.

\section{A definição clássica da morte e sua insuficiência antropológica}

$\mathrm{Na}$ antropologia clássica, o ser humano é concebido como uma unidade substancial de corpo (princípio material) e alma (princípio espiritual). Estes dois princípios antropológicos constituem a unidade ontológica humana. $\mathrm{O}$ corpo é o resultado da ação informante da alma sobre a matéria informe. A vocação da alma é informar o corpo. A união informante da alma com o corpo está presente nas declarações do magistério. O IV concílio de Latrão (1215) descreve a natureza humana como "constituída, de algum modo comum, de alma e de corpo" (DH, n. 800). O concílio de Vienne (1311-1312) define que a "alma intelectiva ou racional que verdadeiramente, por si e essencialmente, confere a forma ao corpo" (DH, n. 900). Seguindo a linha da declaração vienense, Santo Tomás afirma que "a alma intelectiva se une ao corpo como forma substancial" (TOMÁS, S. Th, I, q. 76, a. 4). Neste contexto antropológico da unidade anímico-corpórea, a morte é vista como a ruptura na relação entre o corpo e a alma. Em sua definição natural e clássica, é concebida como a separação da alma do corpo, isto é, como o desmembramento-divisão dos princípios essenciais que constituem do ser humano.

A definição clássica, como separação entre o corpo e alma, não tem fundamentação bíblica, mas está presente na tradição teológica desde a patrística, passando pela escolástica e até chegar à contemporaneidade. Entre os Padres da Igreja, a descrição feita pelo cardeal P. Gasparri é um clássico exemplo da definição tradicional. Segundo esta descrição, "o princípio espiritual do homem, a alma, assume na morte [...] uma outra relação a respeito daquilo que se deseja chamar o corpo" (RAHNER, 1965a, p. 18). Neste acontecimento, a alma cessa de informar e se separa do corpo, tornando-se autônoma. A "alma espiritual pessoal não perece com o dissolver-se da forma do corpo", mas mantém a sua vida espiritual de um modo diverso (RAHNER, 1965a, p. 18). Para esta visão tradicional, na morte, a alma se divorcia do corpo e conquista um novo estado de existência desencarnada. $\mathrm{O}$ corpo sucumbe na morte e a alma segue sua nova condição de existência. Trata-se da desconstrução da unidade antropológica do ser humano de modo que o corpo se decompõe e a alma sobrevive numa nova condição espiritual. A alma subsiste à morte numa condição de separada espiritualmente porque na tradição teológica ela é imortal. A imortalidade da alma está presente em algumas declarações do magistério 
da Igreja. O V concílio de Latrão (1512-1517) afirma que alma racional é imortal e individual (DH, n. 1440). O concílio Vaticano II (1962-1965), na constituição Gaudium et Spes, número 14, declara que alma é espiritual e imortal (DH, n. 4314). Na carta da Congregação da Doutrina da Fé a todos os bispos, em 1979, sobre questões referentes à escatologia, a "Igreja afirma a continuação e a subsistência depois da morte, de um elemento espiritual dotado de consciência e vontade, de modo a existir no tempo intermediário o próprio 'eu humano', carecendo porém do complemento do corpo. Para designar este elemento, a Igreja adotou o termo 'alma' consagrado pelo uso da Sagrada Escritura e da Tradição" (DH, n. 4653).

A definição clássica está presente também na teologia medieval. Segundo Alexandre de Hales (1185-1245), "deve-se dizer que a morte como pena corporal consiste na própria separação da alma em relação ao corpo" (1930, n. 213). Para Alberto Magno (1193-1280), “a pena da morte é a separação da alma em relação ao corpo" (1895, t. 33, tract. 17, q. 113). Segundo Tomás de Aquino (1225-1274), "a morte do corpo não é senão a separação da alma em relação a ele" (1980, c. 229, n. 481). Na contemporaneidade, o teólogo belga, É. Mersch (1946, p. 315), afirma que "a morte é esta decomposição: a separação da alma e do corpo". Para o teólogo espanhol, J. Sagüés (1962, p. 834-835), "a morte é considerada a privação da vida: não a privação da vida eterna, ou seja, o estado de condenação; nem a privação da vida na graça, ou seja, o estado do pecado grave, mas a privação da vida natural, isto é, a separação da alma em relação ao corpo".

Esta visão clássica é antropologicamente insuficiente (BORDONI, 1969, p. 52; RAHNER, 1965a, p. 18-19; BOROS, 1979, p. 123; VOLK, 1967, p. 423). Na realidade, para a definição tradicional, a morte é a separação unilateral da alma do corpo. Ela consiste na fuga da alma da prisão do corpo e a conquista de um estado espiritual ausente de condicionamentos materiais e espaço-temporais. Neste sentido, a alma deveria esperá-lo com ansiedade com o objetivo de se libertar do corpo. Deste modo, o evento afeta somente o corpo enquanto que a alma permanece intocável. É a ruptura da parte imortal, considerada perene e imperecível, da parte mortal, vista como provisória e perecível. Na verdade, afeta somente o corpo, considerado a parte frágil da constituição ontológica humana. Na visão clássica, não é o ser humano que morre, mas somente o seu corpo. A morte é a decomposição do corpo. Separada do corpo e por seu princípio imortal, a alma sobrevive eternamente. Como a alma está ordenada para informar o corpo, logo seu estado desencarnado é ontologicamente precário. Na realidade, com a morte e o fim da função informante da alma, a própria alma deveria entrar em colapso. Mas, como este estágio da vida humana pode afetar somente o corpo se a relação que ele mantinha com a alma era de união substancial e não acidental? Como a morte pode separar o que antes estava intrínseca e mutuamente unido? A relação entre o corpo e a alma não seria mediada pela conveniência enquanto ela não se realiza? Se 
a função da alma é informar o corpo como, com a morte, poderá subsistir em uma condição espiritual de separada?

Um dos problemas da definição clássica está na forma de compreender o tipo de união que vigora entre corpo e alma. A definição clássica entende que a união entre o corpo e alma é tipo substancial, ou seja, há uma relação íntima, profunda e recíproca entre ambos os princípios ontológicos. Neste caso, a morte deveria atingir o corpo e a alma igualmente, sendo a conclusão da totalidade ontológica humana. Porém, a alma, em virtude de um princípio imortal, passa incólume pela morte. Na verdade, na prática, a união entre união entre o corpo e a alma é mais de tipo acidental do que substancial, no sentido que ambos os compostos ontológicos estão unidos ocasionalmente. O corpo e alma estão unidos como dois princípios heterogêneos, independentes e oponentes, sem um vínculo relacional recíproco. Eles são vistos como dois princípios que estão justapostos e acomodados dentro de um mesmo "recipiente" antropológico.

O fundamento antropológico da definição clássica é dualista. Uma visão antropológica integral na qual o corpo e a alma são vistos como princípios que estão ordenados um para o outro, mutuamente relacionados, deve concluir que a morte se refere ao ser humano todo e não somente ao corpo. Neste contexto, ela não é um naufrágio solitário do corpo, mas a alma também, a seu modo, a sofre. É o ser humano na sua inteireza antropológica que morre. Assim, ela não é ignorada enquanto evento antropológico porque tem como sujeito o ser humano como pessoa na unidade mútua e dinâmica de seus princípios ontológicos. Defender a tese da morte como evento que afeta o ser humano na sua inteireza significa excluir um pressuposto antropológico dualista, em que o corpo e alma são vistos como acidentalmente unidos. $\mathrm{O}$ fundamento antropológico e a visão que se tem da morte estão profundamente relacionados. O ponto de partida antropológico determina a definição da morte a que se chega e vice-versa.

A definição clássica demonstra uma visão pejorativa do corpo, o qual é visto como princípio ontológico vulnerável que deve ser sacrificado. $\mathrm{O}$ corpo é reduzido ao seu aspecto físico-biológico e ignorado, por exemplo, em seu aspecto relacional, social e identitário para o ser humano. A definição clássica tem uma concepção espiritualista do ser humano o qual é visto como um espírito puro cujo corpo é um obstáculo, algo perecível e destinado à morte. $\mathrm{O}$ ser humano é reduzido ao período em que alma encontra-se encarnada no corpo. O corpo, na prática, não é visto como um constitutivo essencial da unidade e totalidade antropológica do ser humano, mas sua dimensão heterogênea e provisória. A antropologia que sustenta a definição clássica faz com que o evento seja visto de uma forma docetista (GABORIAU, 1967, p. 13). A definição clássica demonstra uma primazia da alma em relação ao corpo. 
Compreender que o sujeito da morte é simplesmente o corpo, como se percebe na definição clássica, é ter uma visão fisicista, exterior e epidérmica da corporeidade. A definição clássica termina por banalizá-la, concebendo-a simplesmente em seu "aspecto biológico, enquanto se diz fim da animalidade humana, e no seu aspecto filosófico limitando-se à consideração da corrupção substancial da estrutura corpórea do homem" (BORDONI, 1967, p. 57-58). Neste contexto, a morte é algo que sobrevém inesperadamente do externo e atinge o ser humano analogamente ao que ocorre com qualquer outro ser vivente. Assim, a morte do ser humano, enquanto pessoa, não se distingue em nada do puro decesso dos animais, mas é um acontecimento que afeta igualmente a todos como um fato biológico. A vida e a morte são reduzidas ao aspecto biológico, físico e material. A morte para ser considerada "humana" não deve ser vista exclusivamente como um fato bruto ou um fim externo e extremo da existência, mas enquanto um problema que transcende o limite de um fenômeno puramente natural, biológico e animal. Para a definição clássica, "a morte do homem não tem alguma densidade e valor 'humano', mas acontece, por assim dizer, à margem da sua existência pessoal [...] não se reveste de alguma importância pessoal" (BORDONI; CIOLA, 2000, p. 213).

Pode-se concluir que a preocupação da definição clássica não estava voltada para o evento em si mesmo, mas para o que estava escondido atrás dele. A definição clássica não estava preocupada em refletir sobre a relevância antropológica e existencial, mas em garantir e preservar a imortalidade da alma. No fundo, a reflexão clássica está mais interessada no destino eterno da alma do que na morte em si mesma, enquanto evento humano.

\section{A morte é primeiramente um tema antropológico e depois escatológico}

A definição clássica da morte com um acento demasiadamente fisicista terminou por banalizá-la enquanto evento humano. Na realidade, historicamente, o tema da morte não foi considerado seriamente como um objeto de reflexão antropológica e teológica. Ela foi ignorada enquanto um tema de relevância existencial. Isto se verifica porque, além da visão fisicista da morte, a preocupação da escatologia clássica (Novíssimos) estava centrada no discurso sobre o pós-morte. A visão clássica não estava focada no evento da morte, mas nas consequências eternas de sua realização. Ela era vista como fim do status viae (estado peregrinante) "mas para saltar de imediato ao exame do estado correlativo (o status termini), sem se deter em pensar o que significaria para a existência terrena o fato de se encontrar diante de um limite insuperável" (RUIZ DE LA PEÑA, 1971, p. 375). O status 
viae não é visto como um objeto de análise em si mesmo, mas enquanto está a serviço e dá acesso ao status termini.

O discurso antropológico da morte historicamente foi "atropelado" e visto superficialmente em virtude das reflexões a respeito dos temas sobre o pós-morte como o juízo, a imortalidade da alma, a retribuição imediata e outros. Ela era vista como um trampolim para o início das reflexões sobre o pós-morte. Rahner (1965b, p. 109-110, nota 13) afirma que "não se pode saltar a morte passando rapidamente àquilo que vem depois dela". Ou seja, o interesse reflexivo da escatologia clássica estava voltado para aquilo que se ocultava atrás do evento e não com tal evento em si mesmo. Em razão desta constatação, é possível perceber uma ausência histórica de uma verdadeira reflexão antropológica e teológica sobre a morte. Segundo o teólogo italiano Bordoni (1967, p. 57), "se olhamos para o passado, percebemos facilmente que o argumento da morte nunca foi objeto de uma verdadeira e profunda teologia. $\mathrm{O}$ assunto foi considerado ocasião de meditação e de uma meditação salutar pelo seu aspecto terrificante e repelente em sua relação com a culpa: memorare novissima tua et in aeternum non peccabis".

O cenário escatológico era dominado pela preocupação com as realidades do pós-morte. Ela era tratada como um capítulo da escatologia individual. $\mathrm{O}$ tema era visto em uma perspectiva escatológica e negligenciado antropologicamente. Ela não era pensada em e por si mesma, mas enquanto via de acesso às realidades últimas. $\mathrm{O}$ discurso sobre ela não gozava de uma autonomia, mas estava submetido aos temas escatológicos, principalmente ao da imortalidade. Também era visto rapidamente para, em seguida, se refletir abusadamente sobre os temas do pós-morte. Na realidade, a reflexão sobre essa realidade terrena versava sobre a imortalidade. Ruiz de la Peña (1997, p. 802-804), refletindo sobre o binômio morte-imortalidade, propõe que é necessário uma ruptura com a ideia da imortalidade a fim de que o tema da morte alcance uma atenção especulativa.

Uma reflexão antropológica sobre a morte é possível através de sua desvinculação inicial com as temáticas do pós-morte. A ruptura com a ideia de imortalidade propiciará uma libertação do evento, o qual conquistará uma autonomia e independência reflexivas, deixando de ser um argumento subserviente das reflexões sobre o pós-morte. $\mathrm{O}$ discurso sobre a morte tem uma dinâmica própria e não pode ser pensado como um preâmbulo ou exercer uma função propedêutica na reflexão sobre as realidades últimas. Ela é, em primeiro lugar, um tema da antropologia e posteriormente da escatologia. "A morte tem uma problemática própria, distinta da questão da imortalidade, com a qual somente ulteriormente deve ser relacionada" (RUIZ DE LA PEÑA, 1971, p. 114). Ela é primeiramente uma questão, por direito e de fato, da antropologia. A escatologia deve se ocupar das consequências eternas da realização da morte e a antropologia com tal 
evento em si mesmo. Ela deve ser liberta de uma ótica escatologizada e ser considerada, primeiramente, como um evento antropológico. Isto se justifica porque a morte está relacionada com a condição espaço-temporal, corpórea, pessoal, histórica, social, cósmica e contingente do ser humano.

\section{A morte como realidade humana}

Em primeiro lugar, a morte é o fim do ser humano inteiro. O ser humano é uma unidade na pluralidade de suas dimensões ontológicas: corpo e alma. Ele se constitui de uma unidade dos princípios material (corpo) e espiritual (alma). Trata-se de uma unidade substancial anímico-corpórea, psico-física. O ser humano é alma corporalizada e corpo animado. A alma é o princípio da matéria, seu fator estrutural e núcleo informador do físico e do material. O corpo é o produto da informação da alma sobre a matéria. É a alma que confere determinação à matéria que se torna corpo. Através do corpo, a alma se autorrealiza espaço-temporalmente. A interioridade da alma se faz visível e se historiciza no corpo. O corpo e alma são dois princípios metafísicos diferentes, porém mutuamente referidos, que compõem a constituição anímico-corpórea do ser humano. Por sua dimensão corporal, o ser humano se torna um ser-no-mundo, uma realidade mundana. Por seu corpo, o ser humano se localiza e se insere no mundo e se torna sua parte constitutiva. $\mathrm{O}$ corpo humano não consiste simplesmente no seu aspecto físico, visível, epidérmico e exterior, mas é uma realidade co-extensiva ao mundo. $\mathrm{O}$ mundo encontra-se abreviado no corpo e o corpo é um prolongamento do mundo. Assim, o corpo e o mundo são magnitudes que se co-implicam mutuamente. Mediante sua corporeidade, o ser humano também possui uma dimensão social. O corpo "é o meio que tem lugar todo encontro com o outro. Encontro imprescindível para o autodevir da pessoa: esta não pode chegar a si mesma no solipsismo existencial" (RUIZ DE LA PEÑA, 1975, p. 310). Através do corpo, o ser humano é um feixe de relações: consigo mesmo, com o outro, com o mundo e com Deus. A sociabilidade é uma dimensão inerente ao sujeito. O corpo é o veículo mediador do encontro e da comunhão com o outro. Na medida em que a pessoa, por sua relacionalidade, sai de si e vai em direção ao outro, cria comunidade. A relação com o outro é uma condição necessária para a realização e a constituição da identidade da pessoa. A sociabilidade é uma dimensão inerente ao sujeito. A sociedade é mediadora da personalidade. O ser humano é anterior à sociedade a qual é criada em razão de seu caráter social.

Estas dimensões constitutivas do ser humano (unidade anímico-corpórea, mundanidade e sociabilidade) "são radicalmente afetadas pela morte. Ela é: dissolução da unidade (espírito-matéria) do ser; subtração da esfera 
do mundano; ruptura das relações com o outro" (RUIZ DE LA PEÑA, 1975, p. 310). Pode-se acrescentar também que a morte é o fim da condição temporal, histórica, pessoal e livre do ser humano. Ela é um evento que atinge a pessoa, provocando um impacto antropológico, sociológico e cosmológico. Neste sentido, ela não é um evento individualista, mas abrange outras dimensões constitutivas da pessoa (mundana, temporal e social). Ela desmundaniza e destemporaliza o ser humano, o subtrai do âmbito espaço-temporal que o constituía. Desta forma, a morte anuncia a expropriação da condição espaço-temporal do ser humano. Ela é a conclusão das várias dimensões que compõem o ser humano, enquanto um nó de relações. "A morte não é somente negação da vida; é o eclipse do sujeito da vida. É, pura e simplesmente, o fim do homem" (RUIZ DE LA PENAA, 1971, p. 368). É o ser humano inteiro que precipita no abismo da morte. Supor que o sujeito do verbo morrer é o corpo, não o ser humano, equivale a ignorar a seriedade antropológica da morte. Neste sentido, compreender que o sujeito mortal é o corpo e não o ser humano revela uma visão superficial e externa da corporeidade. Ela é um evento que diz respeito ao ser humano e não somente ao seu corpo. O ser humano por sua corporeidade é um ser-para-o-outro, um ser-no-mundo, um ser-no-tempo e um ser aberto para o infinito. Como o ser humano, em sua constituição ontológica, é uma unidade substancial corpóreo-anímica, afirmar que ele é corpo significa automaticamente dizer que ele é alma também. A alma é a alteridade do corpo. Identificar o ser humano puramente com sua exterioridade corporal significa ignorar sua dimensão interna e espiritual, que é a alma. Desta forma, afirmar que o ser humano morre por inteiro significa dizer que a alma também, a seu modo, é afetada pela morte. É preciso "reagir contra a expansiva banalização da morte, que a reduz a um fenômeno epidérmico, como se ela afetasse um corpo adequadamente distinto da alma ou do homem" (RUIZ DE LA PENA, 1975, p. 310). Assim, afirmar que a morte afeta somente o corpo é a manifestação de um desconhecimento de que na corporeidade do ser humano, a alma, que lhe é infusa, também padece a morte. Por isso, é necessário reafirmar que é o ser humano inteiro quem morre (ainda que a alma sobreviva) e morrer significa cessar de ser. A alma é afetada pela morte, mas por sua qualidade imortal sobrevive.

Em segundo lugar, a morte é a possibilidade por excelência do ser humano. Este como um ser que está se tornando, se fazendo e se modelando, existe enquanto projeto e meta a ser realizada. O ser humano é um vir-a-ser e um devir existencial. Neste sentido, o ser humano, por sua dimensão histórica, é um ser que antecipa intencionalmente o seu futuro no presente, se confundindo, em certo sentido, com suas possibilidades: "é na medida em que vai realizando progressivamente suas possibilidades. Porém a possibilidade mais própria e distinta do homem é a morte. Ela é a única certeza ineludível que possui acerca de seu futuro" (RUIZ DE LA PEÑA, 
1975, p. 311). Ela é a possibilidade certa, irrefutável, intransferível e individual do ser humano. Ela é uma possibilidade presente no íntimo da existência desde o momento em que o ser humano começa a ser. O ser humano já nasce condenado a morrer. A morte entra em cena no palco do mundo junto com a vida. Por isso, dizer vida é dizer uma vida que é mortal. A morte é a possibilidade que goza de uma presença medular na vida. No coração da vida pulsa a morte. Ela é a possibilidade que inviabiliza e decreta o fim das demais possibilidades (de concluir um projeto, de realizar um desejo). É a possibilidade com a qual deve ser confrontada todas das outras possibilidades humanas. É a possibilidade absoluta que está na origem de todas as possibilidades. Em razão de seu caráter absoluto, que decreta o não-ser-mais do ser humano, a possibilidade da morte gera uma incancelável angústia. A possibilidade da morte, em sua ameaça constante, é geradora de angústia porque o ser humano se vê na iminência da consumação de sua extinção. Diante desta constatação, a possibilidade constante da morte "se contrasta violentamente com o apetite de ser, próprio de quem se compreende como valor único, insubstituível" (RUIZ DE LA PEÑA, 1971, p. 369). Ou seja, o ser-para-a-morte deseja viver. Em seu caráter absoluto, é a última possibilidade que relativiza todas as outras possibilidades. Sua dimensão de ultimidade não se refere a um sentido cronológico, como a última possibilidade de uma série, mas é a última que está sempre em atuação e possui um caráter de iminência. A vida é constantemente ameaçada pela morte. Ela é a possibilidade última no sentido que é a realização e o cume de todas as possibilidades. Uma vez realizada a possibilidade da morte não é possível tematizar de outra possibilidade no âmbito espaço-temporal. A morte é a certeza implacável do destino humano e "o seu significado retira as disponibilidades do homem" (BALTHASAR, 1986, p. 455). Ela despoja a pessoa de toda referência. Em lugar de relacioná-la, a des-relaciona abruptamente. É neste contexto que se deve compreender que o ser humano é um ser-para-a-morte. "Os demais seres vivos chegam ao fim, mas não são para ele; lhes falta esta ordenação intrínseca, dinâmica, para a morte, que singulariza o homem" (RUIZ DE LA PEÑA, 1975, p. 311). Em sentido autêntico, somente o ser humano morre, os demais seres vivos terminam ou acabam. O ser humano é o único ser mortal que tem consciência da morte. O ser humano é um ser-para-a-morte e, como existência autêntica, tem consciência desta ordenação. Toda existência que deseja ser autêntica deve ser confrontada com a morte. Uma existência concebida à margem da possibilidade mais própria e peculiar do ser humano, a morte, está condenada à inautenticidade.

Em terceiro lugar, a morte goza de uma constante presença na vida. O ser humano possui uma capacidade de antecipar de um modo intencional o futuro no presente que está vinculada à sua finitude natural (que tem o morrer diante de si como possibilidade que pode se realizar a qualquer momento) que outorga à morte um assinalado caráter de iminência. Ela 
goza de uma "presença axiológica em toda a vida humana" (RAHNER, 1965a, p. 41). Devido ao ser caráter iminente, não basta considerá-la como o evento terminal, pois sua sombra se projeta sobre todo o curso da vida. A morte é onipresente na vida humana desde a sua concepção. Sendo a morte uma possibilidade iminente, sua realização é a efetivação de uma possibilidade que sempre está presente. $\mathrm{O}$ ser humano vive antecipadamente a morte como possibilidade ontológica. Ele nasce e vai morrendo lentamente. Desta forma, a morte não pode ser vista como uma possibilidade estranha, surpreendente ou inesperada, mas sempre próxima. Todo o campo existencial da vida é coberto por ela. Uma "existência situada diante de seu limite irrenunciável, perenemente abrigado em sua entranha, pode e deve morrer a morte, e não somente expirar; não a suportar passivamente, mas operá-la" (RUIZ DE LA PEÑA, 1975, p. 312). O ato de morrer significa assumir a possibilidade da morte como própria, como uma ação que se realiza em cada momento da existência e que um dia chegará à sua consumação plena. O ato de morrer é um "fato da vida, encarnada em um existente que se reconhece como um ser-para-a-morte e que usa de sua liberdade em consequência. Enquanto natureza, o homem padece a morte qual necessidade imposta. Enquanto pessoa, tem de ser para ele a ação da liberdade" (RUIZ DE LA PENAA, 1975, p. 312). Ou seja, o ser humano como natureza sofre a morte enquanto uma passividade e como pessoa a assume enquanto uma atividade. É preciso converter o ter que morrer em um ato livre da existência autêntica. Trata-se de passar do aspecto natural ao pessoal da morte. Na realidade, ambas dimensões ocorrem simultaneamente no único evento da morte.

\section{A morte como fim da condição peregrina do ser humano}

A morte como fim da condição peregrina (status viatoris) do ser humano está indiretamente presente na história da teologia seja quando se trata da retribuição imediata logo após a morte (DH, n. 857. 925. 1000-1002. 13041305. 4168), seja quando se condena a tese da apocatástase de Orígenes (DH, n. 411).

A morte é o evento que conclui a condição peregrina do ser humano. Com ela, ocorre o fim do período do mérito e do demérito. Tem-se a cessação do período das decisões humanas. A vida terrena é o período das decisões contrárias ou favoráveis a Deus. Durante a vida terrena, o ser humano pode aceitar ou recusar a oferta de amizade e de comunhão que Deus lhe faz. A morte é o fim da condição peregrina (status viae) e o início da condição definitiva (status termini) da existência humana. Uma vez ocorrida a morte, dá-se a fixação do destino eterno, irrevogável e irreversível da vida humana. Na visão da teologia clássica, depois da morte, iniciam os 
acontecimentos finais da chamada escatologia individual, ou seja, o juízo particular, a retribuição pelas ações boas ou más do ser humano na vida terrena, o céu, o inferno e o purgatório. Esse intervalo escatológico entre a morte e a ressurreição no final dos tempos é denominado de estado intermediário. Neste estado pós-mortal, não é mais possível haver decisões, conversões e mudanças de posições.

O tempo da vida não pode ser percorrido uma segunda vez. O tempo da existência humana é único e irrepetível, assim como é a vida. O símbolo da vida individual, como de toda história humana, não é um círculo, mas uma reta. A história humana é marcada por uma linearidade, cujo acabamento se dá com a morte. Não tem eterno retorno de todas as coisas, pois a história é irrepetível e progressiva. A vida humana é uma história que vai progredindo, sem pausa e nem interrupção, rumo ao seu fim inexorável. A vida humana é marcada por uma singularidade e uma unicidade que desembocam na morte. A vida e a morte são experiências únicas e irrevogáveis. Com a morte, a vida individual chega a uma decisão definitiva. Ela é a última possibilidade que torna a vida definitiva. Por isso, com a morte, a existência humana alcança seu epílogo, sua consagração e sua constituição definitiva. Com ela, ocorre a "definição última daquilo que a livre responsabilidade do ser humano realizou no seu empenho histórico de realização do próprio projeto pessoal" (ANCONA, 2013, p. 290).

Na morte, a dinâmica dos projetos humanos chega ao seu termo e, como momento síntese de todas as determinações livres e realizadas durante a vida, a própria morte se manifesta como evento em que o projeto de personalização do ser humano chega ao seu ápice e à sua plenitude (ANCONA, 2013, p. 290). Ela é a síntese dos projetos e da história das decisões humanas. Trata-se de uma condensação e uma recapitulação da história pessoal do ser humano. Durante o curso terreno da vida, o ser humano vai progressivamente desenvolvendo sua personalidade de modo que na morte o ser humano conquista o apogeu de sua personalização. A "morte é o último momento de maturação da vida humana, pode-se considerá-la como a derradeira auto-realização do homem" (SCHMAUS, 1981, p. 205).

Segundo Lina Boff, "em sentido literal, a morte física é a extinção da vida, da existência, do tempo. Porém, a pessoa humana, por estar destinada à eternidade, é mais que vida, porque ultrapassa o espaço de tempo que transcorre desde seu nascimento até sua morte" (2009, p. 398). A morte não é somente o fim definitivo da linha reta da existência cronológica, mas é também o fim no sentido de uma fixação definitiva do destino humano. Com ela, define-se o futuro eterno do ser humano o qual não é fruto da decisão de um agente superior e externo à existência humana, mas é uma experiência interna da própria morte. A "definitividade da decisão pessoal de toda a vida é um fato intrínseco à morte enquanto ato espiritual-pessoal do homem mesmo" (RAHNER, 1965a, p. 29). A decisão 
do futuro eterno do ser humano não é fruto de uma decisão tomada no momento pontual da morte, como queriam os defensores da hipótese da decisão final, mas é resultado da história de decisões que foram tomadas no curso da vida terrestre. Ninguém será salvo ou condenado por uma decisão pontual tomada no curso da vida terrena, mas pelo conjunto da história das decisões, ou seja, pela opção moral fundamental empreendida durante a vida. A proposição de fé acerca "da definitiva conclusão do status viatoris com a morte significa que a decisão moral fundamental, que o homem amadureceu livremente na temporalidade terrena da sua vida física, na morte se torna definitiva" (RAHNER, 1965a, p. 27). A "morte torna definitiva a orientação que o homem tomou durante a sua vida e que confirmou definitivamente no evento da sua morte" (ZUCCARO, 2002, p. 158).

O momento presente da história humana individual é sempre um instante de decisividade. Existir é ter de decidir a todo momento. Por isso, com a morte, o ser humano, "enquanto pessoa ético-espiritual, na vida física, alcança uma definitividade e completude que torna definitiva a sua decisão tomada de ir ao encontro de Deus ou de distanciar dele" (RAHNER, 1965a, p. 26). A decisão tomada na direção da comunhão ou da recusa de relação com Deus se torna definitiva no momento da morte. Assim, já na vida presente, o ser humano experimenta, por antecipação, a salvação ou a condenação. No futuro escatológico, não haverá surpresa sobre o destino eterno do ser humano. A morte será o momento de confirmação daquilo que o ser humano decidiu e elegeu durante sua vida terrena. $\mathrm{Na}$ vida presente, se define o futuro escatológico do ser humano. O futuro eterno já é antecipado no presente terrestre. O futuro escatológico está ligado à futuridade do presente terreno. $\mathrm{O}$ ser humano caminha com os pés fixos no presente, porém com o olhar voltado ao futuro escatológico. "Toda a vida humana é um processo dialético entre o tempo e a eternidade. No fim se atualiza definitivamente o que amadureceu durante a vida" (SCHMAUS, 1981, p. 202). Por isso, "a morte não é nem o fim do seu ser, nem a pura passagem de uma forma de existência à outra", mas "é o início da eternidade" (RAHNER, 1965a, p. 28). A vida humana "é irrepetível e as decisões tomadas no seu curso têm uma valência eterna" (NOCKE, 2006, p. 137).

A morte comporta uma dimensão moral e religiosa. A dimensão moral significa a consagração da decisão eleita e maturada durante a vida terrena que no momento da morte se torna definitiva. A dimensão religiosa significa que durante a vida terrena o ser humano pode tomar decisões contrárias ou favoráveis a Deus que no momento da morte se tornam irreformáveis e irreversíveis. Assim, ela é revestida de rosto moral e religioso. Com ela, a existência humana conquista uma fisionomia definitiva (BORDONI; CIOLA, 2000, p. 216). 


\section{A morte como paixão e ação}

O ser humano experimenta uma tensão entre aquilo que ele é e o que é chamado a ser. Ele é uma unidade tensional entre natureza e pessoa. Enquanto natureza, o ser humano é uma realidade dada, imposta passivamente, referindo-se àquilo que ele é. Enquanto pessoa, o ser humano é uma magnitude que envolve a vocação, a disposição e a liberdade. Ser pessoa é um chamado e uma decisão na direção de si mesmo. Trata-se de um projeto e de uma construção. É autopossessão. A condição de natureza refere-se à condição prévia e dada. Além de uma unidade dialética de pessoa e natureza, o ser humano é uma unidade entre atividade e passividade, liberdade e necessidade, matéria e espírito, imanência e transcendência.

Esta unidade dialética que constitui o ser humano antropologicamente reflete-se no seu morrer. Assim, a morte é simultaneamente paixão e ação. Do ponto de vista passivo, a morte é uma realidade imposta em razão da condição criatural dos seres vivos. Ela, como paixão, afeta igualmente os seres humanos e os animais. Trata-se de um denominador comum e uma herança entre todos os viventes. Apoia-se em um fato bruto e universal que atinge todos os seres vivos. Ela é vista como um evento biologicamente aceito. É um fato que o ser humano padece, colocando fim à existência física, temporal e histórica. Enquanto paixão, ela é padecimento, ruptura, destruição, decomposição e acontecimento que afeta o ser humano externamente. É uma experiência da morte como um fato estranho, anônimo e impessoal. $\mathrm{O}$ aspecto passivo se refere à dimensão captável fenomenologicamente. É o fim físico da condição humana. Enquanto um evento passivo, a morte do ser humano e do animal não goza de nenhuma diferença pessoal, qualitativa e axiológica. Morrer humano é como o findar de um animal.

A dimensão ativa do morrer é exclusiva do ser humano. Fundamenta-se na índole pessoal, axiológica e qualitativa da morte. Se, enquanto natureza, a morte é uma paixão imposta que o ser humano sofre involuntariamente, enquanto pessoa, a morte é um evento assumido livremente. Trata-se da dimensão interna do morrer, reservada unicamente ao ser humano. Com ela, a pessoa alcança sua definitividade. É um momento de realização humana e pessoal. O ser humano na sua totalidade relacional chega à sua conclusão. No momento da morte, tem-se uma consagração daquilo que o ser humano elegeu ser durante sua vida terrena. É um momento em que o ser humano toma posse de si mesmo e se realiza existencialmente. $\mathrm{Na}$ morte, a existência pessoal se consagra, sendo gerada para a definitividade. A liberdade, enquanto capacidade do ser humano dispor de si mesmo de modo definitivo, alcança sua possibilidade máxima e extrema. A seriedade da liberdade encontra, na morte, seu exercício definitivo. Ela não consiste no momento em que se cumpre o único ato verdadeiramente livre exercido pelo ser humano, mas trata-se de um ato irrevogável da história da 
liberdade humana. Ela é, ao mesmo tempo, autodeterminação definitiva e consagração irrevogável do ser humano enquanto pessoa. Baseia-se no evento em que o ser humano alcança sua máxima personalização e auto-realização. "O término da condição peregrinante do ser humano tem que coincidir com sua cabal identificação, a morte tem que consistir na chegada do homem a si mesmo e, com isso, o começo de sua permanente forma de ser" (RUIZ DE LA PEÑA, 2002, p. 268).

Esta unidade dialética que constitui o morrer humano é compartilhada por vários autores (RAHNER, 1965a, p. 29-30. 37-38; GEFFRÉ, 2004, p. 1198; SCHMAUS, 1964, p. 385; VORGRIMLER, 1981, p. 78-85; TROISFONTAINES, 1960, p. 153-164). O único ato da morte não é composto de paixão mais ação, mas de paixão-ação. $\mathrm{Na}$ unicidade do morrer humano, ocorre simultaneamente a unidade dialética de paixão-ação. Ela é, concomitantemente, um evento externo que sobrevém e afeta o ser humano e um acontecimento ativo e interno que o realiza. É a conclusão e o limite da vida física e a realização pessoal e a consagração existencial definitiva do ser humano. Esta unidade dialética de paixão e ação da morte humana encontra-se presente na morte de Jesus: "A morte de Cristo teve um caráter escatológico, não somente porque foi o término final de sua existência no mundo, mas porque nela cumpriu a entrega definitiva de si mesmo ao Pai e viveu assim de modo supremo sua relação filial com Deus. Não se trata, por conseguinte, do mero fato de morrer, de sofrer a morte violentamente imposta, mas do ato de morrer aceito livremente como entrega de sua vida ao Pai pelos homens" (ALFARO, 1989, p. 791).

\section{A morte como consumação da liberdade}

A morte é fim da história da liberdade humana a qual, por sua vez, ganha um caráter permanente e definitivo. Com ela, a história humana individual chega à sua conclusão. A existência alcança um caráter irreformável e a vida ganha sua fisionomia derradeira. A morte significa a realização da última possibilidade do humano. Com ela, a existência pessoal adquire um caráter irreversível e definitivo. A história da liberdade chega ao seu ponto conclusivo. A liberdade é a faculdade fundamental através da qual o sujeito, em sua transcendentalidade, dispõe de si mesmo em ordem de sua realização definitiva. A liberdade funda a história enquanto a possibilidade de realizar algo realmente definitivo (RAHNER, 1978, p. 575-576). Com a morte, a existência pessoal alcança sua consagração ontológica e chega à sua identidade definitiva, logo a liberdade, no sentido entitativo, conquista seu ponto máximo de realização. A história do ser chega ao seu apogeu.

A essência da liberdade está na possibilidade de uma decisão irrepetível e definitiva do sujeito sobre si mesmo. Esta irrepetibilidade da autodecisão, 
em vista da definitividade e irrevogabilidade, se realiza através de toda extensão temporal dos instantes concretos que constituem a vida histórica da pessoa. A irrepetibilidade da autodecisão acontece no tempo e não é suprimida pela multiplicidade dos instantes. A unicidade desta decisão global do sujeito livre não pode ser entendida independentemente da vida histórica (RAHNER, 1978, p. 576-577). Na morte, a autodecisão do sujeito sobre si mesmo, que possui um caráter definitivo, perpassa todos os momentos das decisões concretas da vida do sujeito e ganha um caráter absoluto. Nas escolhas particulares da liberdade, durante a vida terrena, está presente de modo latente um desejo de irrevogabilidade e eternidade. A opção fundamental que está no subsolo das decisões tomadas no espaço e no tempo ganha uma fisionomia derradeira. Com a morte, cessam todas as possibilidades espaço-temporais. Trata-se da última possibilidade espaço-temporal que decreta o fim de todas as possibilidades finitas. Como a liberdade é a faculdade cujo exercício ocorre no espaço e no tempo, logo, com a morte, o escolhido pela liberdade permanece perpetuamente. Ela está atuando em todo campo existencial e biológico da vida humana como uma magnitude continuamente presente e "por isso a morte é de fato o ato da liberdade do homem. Em relação a isso podemos dizer: o homem deve morrer da sua morte na liberdade, não pode de modo algum evitar esta morte imposta como obra da sua liberdade" (RAHNER, 1965a, p. 78-79). O ser humano deve aceitar livremente a morte e existir numa liberdade para a morte. Com ela, tem-se o fim da história das escolhas e das decisões. $\mathrm{O}$ que foi decidido pela liberdade, em sua opção fundamental, com a morte, chega à sua consagração. Significa a cessação da história da liberdade. Depois da morte, entra em vigor o que foi decidido pela liberdade no tempo.

Não tem sentido pensar que a história da liberdade continua mais além da morte, a qual é concebida como fim da corporeidade histórica do ser humano. Isto suporia situar a autodecisão do ser humano fora de sua história espaço-temporal. Neste sentido, a história seria reduzida à condição de mera aparência que encobre a verdadeira liberdade. Se a história da liberdade segue seu curso depois da morte, enquanto fim da história corpórea, isso significa que a autêntica história nunca esteve presente enquanto tal nessa vida espaço-temporal (RAHNER, 1978, p. 576-577). Porém, a história da liberdade desenvolve sua trama é dentro da história e não além dela. É dentro da história que a liberdade acontece. Com a morte, cessa a atividade corpórea, e considerando que a liberdade está ligada à historicidade do corpo, da finitude e espaço-tempo, logo finda também a história do exercício da liberdade. A liberdade humana é faculdade exercida na finitude, dentro da história e das coordenadas do espaço e do tempo. Assim, cessando a finitude da corporeidade individual finda também da liberdade individual.

É na morte que se dá a manifestação do caráter único e irrepetível da liberdade fundamental. Neste momento, profundamente existencial, o ser humano 
faz uma dupla experiência: primeiramente, o sujeito alcança a consumação do seu existir, chegando ao seu apogeu ontológico. Trata-se do momento em que a biografia do sujeito chega à sua plenificação. Por outro lado, é momento em que o sujeito se torna indisponível, tornando-se despossuído de si mesmo e de todo poder. Na morte, o sujeito não tem mais domínio de sua existência, perdendo a posse de seu existir. A possessividade do existir se dá no âmbito do espaço e do tempo. A disponibilidade do ser e a construção ontológica se dão no campo histórico. A morte representa a expropriação do ser. Com a morte, cessa toda possibilidade de exercício da liberdade e a existência se torna indisponível. É o momento do despojamento do ser. Esta dupla experiência consiste na dimensão ativa e passiva que ocorre simultaneamente na experiência única do morrer: o ativo é o momento da autopossessão de si mesmo e da conclusão da história da liberdade; o passivo é o momento do despojamento e da expropriação de si mesmo. Na morte, se cumpre a liberdade humana não simplesmente do externo, "mas também do interno porque a morte se torna a condição pela qual a liberdade pode alcançar o próprio estatuto de definitividade" (ZUCCARO, 2002, p. 162). "Na morte, o homem parece que é despojado de tudo aquilo que pode dispor de si mesmo e que todos os resultados anteriores de seus atos livres concretos, enquanto integrantes desta única e total autodisposição, ficam apagados" (RAHNER, 1978, p. 580-581). Na realidade, junto com este despojamento, está ocorrendo a dimensão ativa do morrer quando a liberdade em sua capacidade de autodisposição chega ao seu término. Ativamente, no momento da morte, a opção fundamental se torna definitiva.

A morte como uma ação da liberdade não consiste numa hipotética decisão que o ser humano tomaria no momento pontual da vida física. Os partidários da teoria da decisão final defendem que no instante da morte o ser humano conquistaria uma liberdade absoluta capaz de decidir de modo irrevogável, sendo capaz de tomar uma decisão realmente livre. Deste modo, o ser humano não seria capaz de ato realmente livre durante a vida terrena, porque ele ontologicamente ainda não se possui, mas somente no momento da morte. Esta visão desconsidera a história e a seriedade da liberdade e considera somente um hipotético ato da liberdade no momento da morte. O ser humano não é livre somente no momento da morte, mas em todo o curso de sua existência. A liberdade é um patrimônio antropológico que age na vida humana desde a sua concepção. Assim, a liberdade é livre não somente no momento da morte, mas todo o campo existencial da vida humana. A liberdade é uma liberdade para a morte. A autodeterminação da liberdade, visando um fim último, alcança na morte o seu termo. "Com a morte, a liberdade do homem se autodetermina em vista do seu fim último e não resta mais nenhum espaço ulterior para repensar a sua decisão de fundo, na qual ela atuou" (ZUCCARO, 2002, p. 159). 


\section{Uma decisão final na morte?}

No século $X X$, alguns teólogos partidários da hipótese da decisão final (MERSCH, 1946, p. 314-321; GLEASON, 1958, p. 43-77; TROISFONTAINES, 1960, p. 120-151; BOROS, 1979; OLIVEIRA, 2015, p. 855-888 etc) defendem que o momento pontual seria marcado por uma densidade espiritual e psicológica. O momento da morte seria um instante único, atemporal, instantâneo, privado de extensão e sucessão, no qual haveria uma compenetração e uma coincidência entre o status viae (fim do estado peregrinante e da condição histórica em que a alma se encontraria unida ao corpo) e o status termini (início do estado definitivo em que a alma estaria separada do corpo). A morte seria uma passagem atemporal, sem sucessividade, de um estado ao outro. Deste modo, na morte, a alma se encontraria inserida num instante sui generis e espiritualmente denso no qual se deveria tomar sua decisão plenamente pessoal que definiria o futuro de seu ser (BOROS, 1979, p. 62). Na "morte se abre para o homem a possibilidade de seu primeiro ato plenamente pessoal; ela constitui o lugar verdadeiramente privilegiado da tomada de consciência, da liberdade, do encontro com Deus e da decisão sobre seu destino eterno" (BOROS, 1979, p. 30).

No momento da morte, a pessoa conquistaria o seu apogeu ontológico, em termos de liberdade, de vontade e de realização. "Antes da morte o querer é sempre embrionário. A morte constitui o nascimento da vontade [...] é o ato da vontade tal e qual" (BOROS, 1979, p. 73-74). O "primeiro ato total de conhecimento se dá somente no momento da morte quando o espírito se liberta do princípio material [...] A morte é realmente um dies natalis, um dia de nascimento para o espírito, pelo primeiro ato pessoal" (BOROS, 1979, p. 79). A "morte é o lugar da presença total", da percepção da totalidade da realidade ("morte como lugar da percepção total") e da "penetração da nossa existência (morte como lugar de se tornar um com o passado)" (BOROS, 1979, p. 85). Ela seria o lugar da concentração total da existência através da qual se daria uma unidade entre o passado, o presente e o futuro. Neste instante, o ser humano estaria em grau de tomar a sua decisão absoluta. Seria na morte que a existência alcançaria a sua plenitude de consciência, de conhecimento e de liberdade, sendo capaz de tomar uma decisão absoluta que definiria o seu desfecho eterno de perdição ou salvação.

"Na morte, o homem assume a sua forma definitiva e o seu destino se torna irrevogável. Depois da morte, não é mais possível uma mudança de decisão" (BOROS, 1979, p. 140-141). Com ela, a existência daria início a uma condição definitiva. O ser humano receberia sua fisionomia última e uma plenitude definitiva. A definitividade que se daria na morte seria fruto de uma decisão final absoluta, um momento intrínseco da liberdade. A alma, separada do corpo, alcançaria um estado espiritual semelhante à condição angélica, sendo capaz de decisões definitivas. 
"A hipótese da decisão final nos dá a possibilidade de assegurar a todos os homens uma tomada de posição totalmente consciente e absolutamente livre diante do Salvador conhecido pessoalmente" (BOROS, 1979, p. 244). No momento da morte, Cristo se tornaria conhecido por todos os seres humanos (aqueles que não conheciam a Deus ou não o nomeiam como tal, as crianças não-batizadas e mortas antes do uso da razão, os dementes, os pagãos), os quais poderiam decidir pessoalmente o seu futuro eterno (perdição ou salvação) diante dele (BOROS, 1979, p. 161-162). Esta doutrina gera como consequência a concepção da salvação como um dom que seria oferecido, da parte de Deus, a todas as pessoas, sem exceção (BOROS, 1979 , p. 244-245). Deus, em sua vontade salvífica universal, ofereceria a todos os seres humanos, no momento da morte, a possibilidade de uma decisão livre e cabal diante dele.

Esta hipótese foi objeto de muitas críticas (O'CONNELL, 1966, p. 434-442; POZO, 2008, p. 486-487; GRESHAKE, 1974, p. 690-691; RUIZ DE LA PEÑA, 1975, p. 321-325; OLIVEIRA, 2016, p. 141-157) de modo que atualmente não existe praticamente nenhum teólogo que a sustente. A hipótese não considera a seriedade da vida e as ações da liberdade durante a existência histórica. Se os atos livres, durante a vida, fossem realmente considerados não teria necessidade de conjecturar uma decisão final, pois a decisão seria resultado do conjunto da história das decisões na vida terrena. A vida não é considerada na sua seriedade histórica, pois se assim fosse ela não seria objeto de decisão somente no momento pontual da morte. Uma decisão tomada no momento da morte pela alma separada do corpo não pode ser uma decisão humana, mas angélica. Uma decisão realmente humana deve ser tomada pelo ser humano durante sua condição histórica, na sua constituição corpóreo-anímica. O protagonista da história humana é o ser humano todo e não sua alma separada. Para os defensores da hipótese da decisão final, a protagonista da decisão final é alma separada do corpo, demonstrando que o horizonte pós-mortal de tal hipótese é dominado por um espiritualismo e um docetismo. O ser humano seria identificado com o princípio espiritual da constituição ontológica, ou seja, com a alma. Uma reflexão sobre a morte não é uma reflexão sobre o instante pontual da morte. A hipótese não considera a conquista adquirida pela filosofia contemporânea sobre a humanização e a interiorização da morte. A hipótese da decisão final não passa realmente de uma hipótese.

A identificação do status viae com o status termini em um único instante seria contraditória. $\mathrm{O}$ estado de duração anterior à morte, o status viae (temporal, histórico etc.), e o estado de duração posterior à morte, o status termini (definitivo, permanente), não teriam nenhum ponto em comum. $\mathrm{Na}$ realidade, os dois estados possuiriam durações diferentes e contraditórias. Logo, seria paradoxal conjecturar que em um único instante houvesse uma coincidência entre o tempo (estado de prova, homem vivo) e a eternidade (estado definitivo, homem morto). Cada estado tem características próprias 
de modo que os elementos de um seriam incompatíveis com os do outro. Afirmar os elementos de um estado implicaria na exclusão dos elementos do outro. Não seria possível admitir a coexistência, em um único instante, de elementos de estados tão heterogêneos, em termos de duração e características ontológicas.

\section{Conclusão}

Segundo a constituição Gaudium et Spes, n. 18, "é em face da morte que o enigma da condição humana mais se adensa". A relevância do tema da morte consiste no fato de se tratar do enigma humano por excelência. Ela é o mistério diante do qual o ser humano não pode se esquivar, visto que viver significa confrontar-se com a morte. A vida é um confronto diário com a morte. A vida está circunscrita pela morte. O prazo de validade da vida termina com a morte. Não é possível conjecturar um ser humano não se confronte com a pergunta sobre a morte. Ela não é um tema periférico, mas central da vida humana; é uma verdade irrefutável que habita no âmago da existência humana. A relevância da morte está na significação do sujeito que a sofre. Porque o ser humano possui valência onto-axiológica sobre os demais seres viventes, sua morte tem uma significação antropológica.

A morte não tem uma dimensão exclusivamente antropológica, mas também teológica. É preciso dizer que independentemente do pecado original o ser humano é um mortal. A morte não tem sua origem num fato de ordem espiritual ou moral, porque ela entra em cena no mundo juntamente com a vida. A origem dela está na origem da vida. Dizer vida significa dizer uma vida que é mortal. Deus cria um ser humano que é mortal. Ela é o confim da criatura e o elemento diferenciador do criador: a criatura é mortal e o criador é imortal. Deus cria o ser humano mortal e lhe oferece uma vida imortal. No campo teológico, a morte não tem a palavra derradeira sobre a vida, mas a penúltima, pois a última é reservada à ressurreição. Deus manifesta sua potência ressuscitadora diante do poder destrutivo da morte. Deus cria o ser humano para viver eternamente com ele. A vida humana não está circunscrita entre o nascer e o morrer, mas transborda seus limites através da ressurreição. Deus cria por amor e o amor tem uma valência eterna. $\mathrm{O}$ amor de Deus, pela criatura, não está restrito ao âmbito terreno da vida, mas o transcendente amando-a eternamente. Porque Deus é amor, o ser humano não morre para permanecer, mas para ressuscitar. 


\section{Referências}

AlBerto MAgNO. Opera Omnia. Parisiis, 1895. p. II.

ALEXANDRE DE HALES, A. de. Summa Theologica. Florentiae, 1930. t. III.

ALFARO, J. Reflexiones sobre la escatología del Vaticano II. In: LATOURELLE, R. (Ed.). Vaticano II: balance y perspectivas. Salamanca: Sígueme, 1989. p. 789-797.

ANCONA, G. Escatologia cristã. São Paulo: Loyola, 2013.

BALTHASAR, H. U. V. Teodrammatica. Milano: Jaca Book, 1986. v. IV.

BOFF, L. Morte. In: TAMAYO, J. J. (Dir.). Novo dicionário de Teologia. São Paulo: Paulus, 2009. p. 396-401.

BORDONI, M. La morte espressione della libertà umana e incontro personale con Cristo. In: Corso di studi cristiani, destino e attesa dell'uomo Assisi: Cittadella, 1967. p. 54-68.

BORDONI, M. Dimensioni antropologiche della morte. Roma: Herder, 1969.

BORDONI, M.; CIOLA, N. Gesù nostra speranza: saggio di escatologia in prospettiva trinitaria. Bologna: Dehoniane, 2000.

BOROS, L. Mysterium Mortis: l'uomo nella decisione ultima. Brescia: Queriniana, 1979.

CONSTITUCIÓN Pastoral Gaudium Spes sobre la Iglesia en el mundo actual. In: CONCILIO VATICANO II. Constituciones, decretos, declaraciones, documentos pontifícios complementarios. Madrid: Editorial Católica, 1965. p. 209-356. (Biblioteca de los auctores cristianos, 252).

DENZINGER, H. Compêndio dos símbolos, definições e declarações de fé e moral. São Paulo: Paulinas/Loyola, 2007.

GABORIAU, F. Interview sur la mort avec K. Rahner. Paris: P. Lethielleux, 1967.

GEFFRÉ, C. Morte: Teologia bíblica e sistemática. In: LACOSTE, J.-Y. (Dir.). Dicionário Crítico de Teologia. São Paulo: Paulinas/Loyola, 2004. p. 1195-1199.

GLEASON, R. W. The World to Come. New York: Sheed \& Ward, 1958.

GRESHAKE, G. Ricerche per una teologia del morire. Concilium, Brescia, v. 10, p. 687-706, 1974.

MERSCH, É. La théologie du corps mystique. Paris: Desclée de Brouwer, 1946. v. I. NOCKE, F.-J. Escatologia. Brescia: Queriniana, 2006.

O'CONNELL, M. J. The mystery of death: a recent contribution. Theological Studies, USA, v. 27, p. 434-442, 1996.

OLIVEIRA, R. A. O instante da morte. A hipótese da decisão final (I). Revista Eclesiástica Brasileira, Petrópolis, v. 75, n. 300, p. 855-888, 2015.

OLIVEIRA, R. A. O instante da morte. A hipótese da decisão final (II). Revista Eclesiástica Brasileira, Petrópolis, v. 76, n. 301, 2016, p. 141-157.

POZO, C. Teología del más allá. Madrid: BAC, 2008. 
RAHNER, K. Sulla teologia della morte. Brescia: Morcelliana, 1965a.

RAHNER, K. Saggio di uno schema di dogmatica. In: Saggi teologici. Roma: Paoline, 1965b. p. 51-111.

RAHNER, K Il morire cristiano. In: FEINER, J.; LÖHRER, M. (Dirs.). Mysterium Salutis. Brescia: Queriniana, 1978. v. 1, p. 557-594.

RUIZ DE LA PEÑA, J. L. El hombre y su muerte. Burgos: Aldecoa, 1971.

RUIZ DE LA PEÑA, J. L. La otra dimension. Madrid: Eapsa, 1975.

RUIZ DE LA PEÑA, J. L. Muerte. In: VILLA, M. (Dir.). Diccionario de Pensamiento Contemporáneo. Madrid: San Paolo, 1997. p. 802-807.

RUIZ DE LA PEÑA, J. L. La pascua de la creación. Madrid: BAC, 2002.

SAGÜÉS, J. F. De Morte. In: PATRES SOCIETATIS IESU FACULTATUM THEOLOGICARUM IN HISPANIA PROFESSORES. Sacrae Theologiae Summa. Madrid: La Editorial Católica, 1962. v. IV, p. 833-848.

SCHMAUS, M. Dogmatica Cattolica. Torino: Marietti, 1964. v. IV/2.

SCHMAUS, M. A fé da Igreja. Petrópolis: Vozes, 1981. v. 6.

TOMÁS DE AQUINO. Compendio de Teologia. Madrid: Rialp, 1980.

TOMAS DE AQUINO. Suma Teológica. São Paulo: Loyola, 2002. v. 2.

TROISFONTAINES, R. "Je ne meurs pas...". Paris: Éditions Universitaires, 1960.

VOLK, H. Morte nella teologia. In: FRIES, H. (Org.). Dizionario Teologico. Brescia: Queriniana, 1967. v. II, p. 414-425.

VORGRIMLER, H. El cristiano ante la muerte. Barcelona: Herder, 1981.

ZUCCARO, C. Il morire umano. Un invito alla teología morale. Brescia: Queriniana, 2002.

Artigo submetido em 16.10.2020 e aprovado em 12.04.2021.

Renato Alves de Oliveira é doutor em teologia dogmática (2011) pela Pontifícia Universidade Gregoriana de Roma. É professor adjunto do departamento de teologia da PUC Minas (BH) e pesquisador de temas como a morte, o corpo, a alma, a relação corpo-alma, a pessoa, a liberdade e as relações entre a antropologia e a escatologia cristãs. Orcid.org/0000-0003-01543448. E-mail: praobh@yahoo.com.br

Endereço: R. Prof. Florestan Fernandes, n. 66 - Apto. 602

Minas Brasil

30535-680 Belo Horizonte - MG - Brasil 